\title{
ペアレントトレーニングにおける親子の状態像に応じた アセスメントと介入方法の検討
}

\author{
○吉田遥菜（早稲田大学大学院）・野中俊介（東京未来大学） - \\ 堀川柚 (早稲田大学大学院) - 嶋田洋徳 (早稲田大学) \\ キーワード : ペアレントトレーニング，親子相互作用，アセスメント
}

\section{目 的}

従来, ペアレントトレーニング (Parent training ; 以下, PT) の有効性が多数報告されている（たとえば，免田他，1995）。 一方で, PTを実施したものの, 生活において親の関わりの変 化が子どもの適応行動の増加に必ずしも機能しない場合があ ることも報告されている（井澗・上林，2011）。

このような PT の効果が一貫していない背景として, 親子 双方の個人差によって, PT の訓練場面において獲得したはず のスキルが，実際の生活の中の子育てでは遂行できていない 場合があると予測される。PT の効果を左右する親側の個人 差としては，PT の直接的な目的としている親側の養育行動 のレパートリーの獲得の程度を基盤として，間接的にそれに 影響するとされる「育児ストレス」や「行動変容の知識」な どがあることが多くの研究から示唆されている（たとえば, 日下部, 坂野, 2001)。一方, PT の効果を左右する個人差と しては親側の特徴だけではなく, 障害種別や認知発達段階の 状況などの子ども側の特徵も含まれると考えられる。

しかしながら，これまでの研究においては，このような親 子双方の状態像の記述に相当する具体的な変数, およびそれ らのアセスメントを踏まえた介入方法に関する理論的検討は 十分に行われているとは言いがたい。そこで本論考では, PT の介入効果を高めるために, 親子双方の状態像を適切に記述 する認知行動的变数を整理し，その变数のアセスメントに応 じた介入方法を検討することを目的とする。

\section{方 法}

国立情報学研究所 NII 論文情報ナビゲータ（以下，CiNii） を使用し，「ペアレントトレーニング」のキーワード検索を行 った（2019 年 6 月）。その結果，合計 349 編の論文が収集さ れた。収集された論文の発行年は, 2002 年から 2018 年であ った。次に, 収集された 349 編のうち,（a）査読付学会誌に て公刊された論文である，(b)「支援者が親に対して具体的な 養育技術に関する知識やスキルを教授し，実際に親が子ども に対して指導を実施している」という内容が記載されている もの，または記述内容から親が子どもへ指導していると判断 できる実践論文，(c)幼焂から小学生の親を対象としている， という 3 つの基準を満たす論文を抽出したところ, 28 編の論 文が抽出された。さらに，ハンドサーチによって分析対象論 文において実践されたペアレントトレーニングに関する参考 の文献 1 編を加えた。これらによって, 最終的に 29 編の論文 が分析に用いられた。本論考は, 発表に関連し, 開示す心゙き 利益相反関係にある企業などはない。
結 果

全ての研究において, 適切な養育行動の獲得を目指してい たが，その際に合わせて考慮すべき変数や PT の実施により 他にも変容可能な変数などを含め, PT の効果を左右する親側 の具体的な個人差変数として,「養育行動」「行動変容の知識」

「養育態度」という行動に関連する変数,「育児ストレス」と いう情動に関連する変数,「育児エフィカシー」「育児ソーシ ヤルサポート」「モニタリング能力」「子どもの行動に対する 認識」という認知に関連する変数の 8 個の変数に集約できる と判断した。また, 子ども側の個人差としては, 発達障害特 性や, 自身の行動に随伴する結果に着目する能力が発達にと もなって可能になることが示された。

\section{考 察}

本論考の結果から, PT の実施によって, 介入場面で獲得し たスキルを実際の家庭場面で用いることが難しかったり，子 どもの反応に期待してしまうと, かえって育児ストレスが高 まったりなどのように，個人差変数を考慮する必要があると 考えられる実践も多く見受けられた。このことは, 従来のPT の限界として，PTにおける「手続き」に着目するあまり，認 知行動療法が重視する「機能」の要素が相対的に見過ごされ， 結局は養育行動の「形態」の変容に重きが置かれてしまって いた可能性があると考えられる。したがって, 親子の良循環 的な相互作用を目指寸際には，「機能的側面」にあらためて焦 点を当てる必要があると考えられる。このように PT におい て親子の相互作用の「機能的側面」に着目するという前提を もって考えると, 養育行動の結果である子どもの行動を親自 身で予測して行動できるかという結果を見る力(野口, 2003)， すなわち「随伴性知覚」や育坚に対する考え方や価值観であ る「育児信念」（清水，2003）などの個人差变数が大きく影響 している可能性があると考えられる。また, 今後の PT 実践 においては新たに子ども側の認知行動的特徽やその発達段階 という観点も十分に踏まえる必要があると考えられる。

以上のことから，今後の PT 実践においては，これまで重 視されてきた個人差変数に加えて「随伴性知覚」や「育児信 念」という観点も踏まえて, 親側と子ども側双方の認知行動 的特徵を丁寧にアセスメントすることによって, 実際に選択 した養育行動に随伴する子どもの反応を確認するという，親 子の相互作用の「機能的側面」を最重要視した介入を行う必 要があると考えられる。

(YOSHIDA Haruna, NONAKA Shunsuke, HORIKAWA Yui, SHIMADA Hironori) 